\title{
TAIWAN ELEMENTARY TEACHERS' VIEWS OF SCIENCE TEACHING SELF-EFFICACY AND OUTCOME EXPECTATIONS
}

Erratum to: Liu, C-J., Jack, B. M., \& Chiu, H-L.(2008). Taiwan elementary teachers' views of science teaching self-efficacy and outcome expectations. International Journal of Science and Mathematics Education, 6, 19-35. DOI: 10.1007/s10763-006-9065-4.

Due to a communication failure, the order of the names of the authors is not right. The order should read: BRADY MICHAEL JACK, CHIA-JU LIU, and HOUN-LIN CHIU.

Graduate Institute of Science Education

National Kaohsiung Normal University

62 Shenjhong Rd, Yuan Cha Township, Kaohsiung County,

Taiwan, 824, Republic of China

E-mail: chiajuju@ms26.hinet.net

The online version of the original article can be found at http://dx.doi.org/10.1007/s10763-006-9065-4.

International Journal of Science and Mathematics Education (2008) 6: 437

(C) National Science Council, Taiwan (2008) 